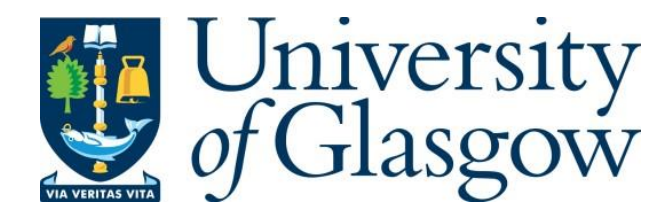

Beveridge, R. and Koch, P. (2019) Contesting austerity, de-centring the state: antipolitics and the political horizon of the urban. Environment and Planning $C$ :

Politics and Space, (doi:10.1177/2399654419871299)

There may be differences between this version and the published version. You are advised to consult the publisher's version if you wish to cite from it.

http://eprints.gla.ac.uk/193332/

Deposited on: 16 August 2019

Enlighten - Research publications by members of the University of Glasgow http://eprints.gla.ac.uk 


\title{
Contesting austerity, de-centring the state: anti-politics and the political horizon of the urban
}

\section{Ross Beveridge \& Philippe Koch}

\begin{abstract}
This article draws novel links between 'anti-politics', austerity and a political horizon centred on the urban. Research on anti-politics often invokes a binary understanding of a politics of and within the state and an anti-politics at a distance from or hostile towards the state. This article argues that in the context of austerity, this binary loses traction. Austerity has intensified the transformation towards networked forms of governance within which the state becomes a more hybrid entity of contradictory ideals and practices. Austerity not only calls into question the legitimacy of formal politics because of its devastating social outcomes, it also disaggregates the political authority of the state and opens up a particularly urban terrain of politics. We capture this development by examining the intersections between the local state and the urban field of politics. Looking across the struggles against austerity in Europe, and focusing in more detail on housing politics in Berlin, we assert that the urban is important not only as a setting (as typically argued) but also as the basis for a different rationality of political action in and against austerity. In the context of austerity struggles, the state authority becomes ever more contingent and other, more urban, forms of politics advance. In sum, the article contributes to a spatial reading of (anti-)politics against austerity, points to the de-centring of the state in transformative political projects and emphasizes the analytical purchase of a distinctly urban perspective on contemporary politics in European liberal democracies.
\end{abstract}

Keywords: austerity, anti-politics, urban, social movements, the state, Berlin 


\section{Introduction}

This article develops links between 'anti-politics', austerity and a political horizon centred on the urban. It is argued that politics in and against austerity entails potentially significant shifts in terms of the spatiality and rationality of politics. Austerity, as understood in this paper, is not just a global policy paradigm with destructive socio-economic outcomes (Peck, 2012; Streeck and Mertens, 2011; Fuller and West, 2017). Depending on the specific context, austerity also impacts on intergovernmental relations, local decision-making processes, the distribution of (economic) risks and dependencies and forms and intensities of political mobilization and possibilities (Davidson and Ward, 2018; Peck, 2012). Austerity transforms to different degrees how institutions of the state operate as well as the relations between governmental, economic and civic arenas. Our point of departure in this article is to consider how austerity calls into question the legitimacy of formal politics, the authority of the state, and how these transformations shape and are being shaped by contestatory urban forms of politics.

We present the reconfiguration of politics through austerity as a dynamic, on-going process in which the logics and points of engagement between state and society are being transformed. The narrative of (local) state failure that underpins and seeks to legitimize austerity as a reasonable reaction to the fiscal crisis undermines at the same time the primacy of state-embedded politics to tackle austerity-induced harms (Peck, 2014). But the political contests resulting from austerity are inherently complex because austerity also increasingly reconfigures the terrain of politics in diverse ways (Jessop 2016). We argue that the political strategies and practices employed to counter austerity offer complex and evolving understandings of the (local) state and its place in urban politics.

At first glance, austerity might be seen to make the capture of the state ever more crucial, i.e. to use the state to reverse austerity. However, in most parts of Europe, this scenario appears highly problematic as the formal realm of politics - the means through which state power is formally wielded and distributed - has offered few if any alternatives to austerity, even if left and left-of-centre parties have been in government. In recent years, and particularly since the economic crisis of 2008-2009, austerity joined, even merged, the list of inescapable self-evident policy "truths" (e.g. the necessity of privatization and marketization) in the context of dominant global markets. In short, most European mainstream political parties no longer attempt to mediate between the interests and rights of citizens and the interest of capital accumulation (Streeck, 2016). Austerity in Europe can thus be seen as the gathering 
crisis of modern liberal government: the point where the predicament of capitalism and the predicament of liberal democracy meet and the political elite retreats from the realm of politics (Mair, 2013).

Given this we might assume, following Mair (2013), that citizens would, understandably, also retreat from the realm of politics. The term "anti-politics" has risen to prominence in the Anglo-American discourse to capture the disenchantment of citizens with formal politics (see Clarke et al., 2018). Much of the anti-politics literature focuses on intensifying public disengagement and hostility to politicians and parties within the neoliberal paradigm (e.g. Clarke, 2015; McDowell et al., 2014; Stoker, 2006; Hay, 2007). Because of this, there is a tendency in the literature to define anti-politics as an ill, something to be cured, or a 'lack', which needs to be filled (Tormey, 2015: 10). However, for scholars departing from a more radical perspective, antagonism to formal politics and the state can be both expected and necessary - part of a general skepticism about the potential for transformative change within the institutional boundaries of liberal democracy. Put differently, then, "anti-politics" might in some cases be better defined as anti-liberal politics: as generally indicative of being against a specific form of politics, i.e. the formal politics of liberal democracy, rather than politics per se.

In this article our sympathies lie with the radical understandings of contemporary 'anti-politics'. However, we argue that it is necessary to go beyond the binary often invoked in radical as well as liberal perspectives on the contemporary conjuncture: of a politics of and within the state and an antipolitics at a distance or even hostile towards the state. In the context of austerity, it is argued that this binary loses purchase. Austerity has intensified the hybridization of the state (Davies and Blanco, 2017) and the more general transformation towards networked forms of governance. Austerity calls into question the legitimacy of formal, representative politics because of its devastating social outcomes, but also because it disaggregates the political authority the state once (allegedly) had as it modifies the state. This is especially true of the local state, which has become a more hybrid entity of networked political governance with paradoxical epitomes and practices.

We propose a spatial reading of the intersections between austerity and anti-politics. Peck states that struggles over and alternatives to austerity are likely to have "an intensely urban form as cities become beachheads and staging grounds for both fiscal revanchism and progressive forms of counter-politics (Peck, 2012: 651)." We emphasize that these struggles are urban not simply because they occur in urban settings or that cities and towns provide useful stages for resistance. Rather, the urban is both a source and stake of politics. Wider urban political practices are crucial to these resistances and 
contribute to the reshaping of the state and the political terrain. The urban offers, we propose, a locus and rationality of politics, perhaps even an alternative to the state-centred institutional realm of modern liberal democracy.

Empirically we look across forms of urban resistance to austerity in Europe and present a more detailed examination of housing politics in Berlin, based on an analysis of recent secondary and primary sources. Austerity is implemented and opposed to a large extent in cities, towns and neighborhoods. It is the local state that transforms austerity into everyday practices. The local state serves as a transmitter of austerity and an arena of contestation at the same time. Therefore our empirical focus is on the intersection between austerity, anti-politics and the local state. We understand this intersection as an ambiguous political field carrying multiple logics and, potentially, enables transformative political agency. This political field serves as an instructive empirical setting to reflect upon the ways antipolitics emerges as a reaction to the transformation of the state under austerity and at the same time reconstitutes the local state as a democratic project of urban politics.

The article proceeds in the following steps. Section 2 outlines briefly the anti-politics literature, contrasting the dominant liberal understanding of politics underpinning the mainstream literature with a more radical interpretation. The section concludes by problematizing a simplistic binary understanding of proper state politics versus anti-politics beyond and in opposition to the state. In section 3 we focus on urban resistances to austerity in Europe as a form of anti-politics, identifying common tropes in the intersection between the transformation of the local state and urban political practices. In section 4 we provide a more detailed look at housing politics in the context of austerity in Berlin, showing how austerity itself has reshaped the (local) state and how political struggles seek not to destroy it but to de-centre it. The final two sections are theoretical reflections on this empirical case: First, with a focus on the intersection between urban forms of political action and the local hybrid state (section 5) and, second, with a focus on the distinct urban horizon of these struggles (section 6). Section 7 concludes the paper by considering what this urban horizon might contribute to our understanding of transformative politics and liberal democracy.

\section{Who's afraid of "anti-politics"?}

\section{Citizens against liberal politics?}

While it is perhaps pointless to seek a defining characteristic of the current political conjuncture, given the unpredictability and turbulent mix of dynamics apparent, the notion of "anti-politics", certainly captures something particular about current times. Seen in longer perspective, there is no single 
uniform interpretation of "anti-politics", with the term used in very different ways in different contexts and the related term "anti-political" referring to an elimination of the "political" per se (Schedler, 1997). However, in contemporary Anglo-American political science as well as media debates (Leonard, 2014; Brooks, 2016) anti-politics usually refers to negativity towards the realm of politics itself (Clarke et al., 2018; Fawcett et al., 2017). According to Clarke et al. (2018: 2-4) anti-politics is an important and worrying feature of the contemporary political conjuncture because it is not simply a dose of healthy scepticism, inherent to functioning democracy, nor simple apathy or indifference, but disenchantment with formal politics as a means of securing democracy and hostility to those who work within it - politicians, bureaucrats, experts.

While this negativity might be related to other facets of the political conjuncture, such as the neoliberal purge of the political (i.e. "depoliticisation" e.g. Hay, 2007) or the dominance of a global economic elite over a ceremonial political system (i.e. "post-democracy", Crouch, 2004), the particularity of the anti-politics lens is that it hones in on the (failing) relationship between citizens and formal political institutions. Certainly there is ample if uneven evidence of this in both longerterm trends in voter turnout, political party membership, as well as more short-term manifestations of extreme hostility to politicians and the paradoxical rise of right-wing political parties whose support rests in large part on their aggressive stance to the very system they are seeking to gain control of (Kriesi, 2014; Clarke et al., 2018). In much of the recent literature anti-politics is viewed as a problem because it means that members of society are turning away from liberal democracy. Without overstating the similarities between them, a number of key political science works (e.g. Flinders, 2012; Stoker, 2006), from a broadly liberal perspective, conceptualise anti-politics almost entirely as a threat and that the best if only way of dealing with it is through reinvigorating participation in formal politics (cf. Clarke et al., 2016).

However, more radical scholars tend to take a different view of both the current political conjuncture and the tendencies identified as anti-politics, ultimately arguing that an oppositional stance and distance from formal politics and the state is inherent to transformative politics. For example, scholars have countered the sense of a deficit in politics characteristic of much contemporary critique -that citizens are merely disengaging - by arguing that while formal politics may be declining, a rebirth of politics beyond the formal sphere is ongoing, one characterised, for example, by grassroots organizing (Wainwright 2018), post-representation and spontaneity (Tormey, 2015) and not aimed at gaining state power (Newman, 2015) but forging new ways of being political (Della Porta, 2013). Such analyses rest on critical understandings of the potential of liberal democracy as both theory and practice and offer a 
different approach to the relationships between the institutions, norms and practices of formal politics and the problems we see in the current conjuncture.

To think more incisively about this political conjuncture, and the place of formal politics within, it is necessary to step completely outside of the conventional liberal framing of (anti-)politics and engage with other political traditions. Developing political alternatives to austerity or neoliberal policy is not simply about transforming existing economic arrangements - it may also necessitate new forms of democratic political practice. Thus antagonism to the formal political realm is central to transformative change - what Tormey and Gagnon (2017: 99) call a "political anti-politics" is crucial. While political anti-politics is of course not the preserve of the left, and could include right wing nationalism, it is defined by the intent to disrupt the status quo of politics. Abensour (2011) goes further. He has argued that true democracy can exist only in the struggles of the demos against the state and institutions of formal politics. In a similar vein, concepts such as "post-democracy" (Crouch, 2004) or the "postpolitical" (Rancière, 2009) capture the sense that the current political conjuncture, and liberal politics more generally, fail to provide genuine democracy and proper democratic political contestation. Democratic processes have become ceremonial and the political realm has been hollowed out (see especially Crouch, 2004). From such a stance, the production of alleged "inevitable policy truths" such as austerity have narrowed political action to preclude alternatives to the norms and interests of global markets. The very lack of democratic political exchange within formal political systems can be seen as generative of anti-politics, either simply disengaged from or hostile to politicians and parties or more productive and transformative. Following Ranciere in particular some radical scholars contend that true political agency disrupts the instituted political order in antagonistic moments (e.g. Wilson and Swyngedouw, 2014). Others are critical towards this opposition between a true political moment or space and the existing order of politics and emphasize different terrains and temporalities of political actions blurring the boundaries between "proper" politics and its other (e.g. Barnett, 2017).

\section{Rethinking the state-society binary in anti-politics}

Understood in either liberal or radical terms, anti-politics may be more (i.e. engaged and in opposition) or less (i.e. disinterested and withdrawn) political but it rests on an antagonistic relationship between society and the formal political system centred on the (nation) state. There is a tendency in both liberal and radical perspectives to assume a binary between state and society when considering problems and possibilities. In part, the resulting debate rests on whether new loci of politics are emerging beyond formal politics and whether we should embrace them or redefine and reassert the formal system (see Clarke et al., 2018; Tormey, 2015), and the extent to which democracy rests on flourishing contestation 
as opposed to building consensus (Barnett, 2017). But as will be shown below in the struggles against austerity, seeking to draw lines between formal and extra-formal politics, state and society, is increasingly problematic. If the nation state has not quite lost its sovereignty, it has certainly been disaggregated in recent decades Hardt and Negri, 2000). Austerity is further reshaping the political terrain. The roles of the state and formal political institutions are evolving, not predetermined. It is necessary to look at the intersections where formal and extra-formal politics meet and react to each other (Beveridge and Koch, 2017a, 2017b).

Diverse theorists of transformative politics argue that is both inaccurate and unhelpful to think in terms of reified boundaries between the formal politics and extra-formal politics. Trying to characterize recent forms of leftist political activism, Tormey's (2015: 140-142) notion of "postrepresentative democracy" captures well this sense of both a departure from formal politics and its continuing if changing presence and potency.

A transformative (anti-)politics may be seen to engage with formal politics and is not only in antagonistic relations with it, but is also enacting alternative horizons and political possibilities beyond it. From a "post-anarchist" perspective Newman (2011) makes a similar point by stating that radical politics always rests on a generative politics-anti-politics dialectic, one that only has "a consistent identity if an anti-political, indeed utopian, dimension is also present-otherwise it remains caught within existing political frameworks and imaginaries" (Newman, 2011: 323). Equally, anti-politics, so defined, can only have traction if it engages with power and the basics of politics: "building, constructing, organizing, fighting, making collective, decisions and so on" (Newman, 2011: 323). It has to engage with nodes of power apparent in existing political institutions at different levels (Beveridge and Koch, 2017b). Marchart (2015) has made a similar general point about the project of radical democracy being defined by its inherent antagonisms, which fuel the search for political means to achieve transformative change rather than resting on specific and set ways of being political.

From such a stance, we by-pass the problems presented by the conventional state-centred view of (anti-)politics, which ontologically de-centres and normatively "de-merits" ways of being political which threaten this given order of politics (Magnusson, 2011, 2014). That this perspective might be problematic becomes especially obvious in the current period of austerity where the state is cast not only as responsible for the fiscal crisis but also, enacts the regressive redistributive policies that define the politics of austerity (Peck, 2012). Avoiding reifying the state also, however, allows us to better account for the complex ways in which the local state itself is changing through austerity, is not simply 
attacked, as the main form of contestation, but is often de-centred in political responses to austerity. In such cases, neither winning nor destroying the local state is the prime concern. Nor is the local state irrelevant - far from it, but it is rather increasingly located on a different political horizon shaped by wider urban political practices and spatial production.

In the following section we approach the political field, where austerity, anti-politics and the local state meet, through a review of recent struggles in European cities. We identify three tropes of resistance to austerity in Europe, around which instances of anti-politics, transformative practices and political agency/alliance congregate.

\section{Anti-politics in and against austerity}

In reaction to austerity, political organization and mobilization have grown massively in urban Europe. There is often an element of immediate self-help to extract or build on urban resources to make ends meet. But they are frequently more than that. We can see a range of initiatives from pragmatic interventions in particular urban places (Tonkiss, 2013) through more radical projects of autonomy to confrontational "politics of transformation" (Peck, 2012) attempting to recapture the local state (Davies, 2017).

Depending on the specific urban place where they emerge, these political reactions pursue different strategies and make different claims. Indeed, resistance and its success against austerity are very uneven, as the instructive case studies developed in the CURA projects show (Davies et al., 2018; Pill, 2018; Pill and Guarneros-Meza, 2018; Gaynor, 2018; Blanco et al., 2019). Nevertheless, we can delineate some common tropes, practices and strategies apparent across different cities: (1) a confrontational stance towards austerity governance and attempts to reimagine local state spaces; (2) political practices problematizing (individual) property rights over urban land/space; (3) a politics of solidarity built around new alliances both in terms of opportunities to participate politically and in terms of who should benefit from local policies.

\section{Challenging austerity governance and attempts to reimagine local state spaces}

We can observe that political practices against austerity challenge how the state tries to govern austerity (Davies et al., 2018). They all question the legitimacy of how the local state translates austerity into actions eroding the tissue of urban everyday life. In some cities, alternative forms of collective organization emerge deliberately detached from existing state spaces. They include workers' occupied work-places, self-organized cooperatives, social centers, squats, time banks, alternative 
currency networks and many more (Arampatzi, 2017; Daskalaki, 2017). These "quotidian and everyday practices of activism" (Stavrides, 2014: 50) have translated moments of political contestation into a transformative process embedded in communities and with temporalities at one remove from the local state.

Other examples do directly engage with and try to transform the local state by reimagining and practicing how a transformative local state would look like. The case of En Comù in Barcelona was exemplary (Blanco et al., 2019). En Comù is a radical left platform encompassing different social movements and political organizations. In 2015 En Comù won the local elections and held mayoral office until 2019. Autonomy from state spaces was apparent in their very different vision of what a (municipal) state is. It was also evident in their attempt to free municipal politics from the economic relations and institutions to which it is usually beholden (Blanco et al., 2019: 11). This form of resistance goes beyond a binary understanding of the state-society relation as it acknowledges on the one hand that "the institution is not associated with the possibility of rupture. The institution is associated with governing what is possible and what actually exists" (Colau cited in Blanco et al., 2019: 12). But on the other hand, En Comù attempted to transform the way "the institution" operates by "enhancing the channels of public control, citizen participation, and public-community co-production of public policies" (Blanco et al., 2019: 11). In other words, this form of resistance works in and with the differentiated character of urban governance and attempts to take the struggle between political coalition into the workings of the local state (Blanco, 2015).

\section{Individual property rights or shared urban property}

Another trope discernable in anti-austerity politics is the problematization of private property rights and, more generally, a resistance to new forms of urban enclosure (Hodkinson, 2012) as well as a demand for "radical forms of coproduction and commoning gispep (where "commons" refer to resources held istepin trust for, belonging to or affecting a whole community, but not under direct state control)" (Davies, 2017). Such political platforms exist in different cities related to a variety of domains, such as, but not limited to, water (Hearne, 2015; Gaynor, 2018; Beveridge, Hüesker and Naumann, 2014) or housing (O'Callaghan et al., 2018; Bresnihan and Byrne, 2015).

In some cities, the urban commons are part and parcel of the political platform, in other places such as Dublin, urban commons emerge out of alternative non-formal spatial practices. And yet, both routes articulate the contingency and contestability of private property in cities and private enclosures of urban spaces. Blomley $(2019,2017)$ has argued that the effectiveness of private property is reliant on 
the state and/or on its recognition by the public. Challenging private property articulates a political antagonism where the state and the public must answer a crucial question: Should the state defend and protect individual property rights or uphold the possibility for community members to re-appropriate and use urban resources? Thus the problematization of private property implies the contestation of the liberal democratic state.

\section{A politics of solidarity}

The last trope touches on a fundamental aspect of politics: who can participate and what forms of coalition are possible? Anti-austerity struggles in different cities demonstrate how new alliances can be formed and maintained across different segments of the population (Di Feliciantonio, 2017; Gaynor, 2018). Mayer (2013) states that alliances around the urban everyday emerge that crosscut existing social boundaries between middle-class movements and the urban precariat (Mayer, 2013). Arampatzi (2017) reports in great detail on how spatial practices to "re-appropriate certain areas of the neighborhood from exclusion and repressive tactics" led to increasing support from residents and other community organisations. These practices grounded in the everyday facilitated a "politics of solidarity" which not only acknowledges differences but "locates the strength of cooperation and solidarity among the multiple responses that can emerge to the same issue" (Arampatzi, 2017: 53).

\section{Contesting austerity realism: Housing politics in Berlin}

In this section we zoom in a little closer to political struggles in the context of austerity. Focusing on the case of housing struggles in Berlin the purpose is to take a more detailed look at the intersections between the local state and wider urban politics. While the financial status of most German municipalities has declined in recent years, the case of Berlin is instructive for different reasons: in Berlin austerity policies were in place well before the financial crash in 2008 and have exerted considerable influence on politics within the city. Berlin is thus a key example of, to follow Peck (2012: 651), the urban beachheads of austerity where fiscal revanchism is confronted with diverse forms of progressive political activism (see Holm, 2014).

$A$ (very) short history of the impact of Berlin's austerity policy on housing

Austerity policies in Berlin emerged in the wake of socio-economic restructuring after reunification in 1990 at both the national and local level. Berlin is a city-state, both a 'Land' or state, with responsibilities across public sectors such as housing, transport and health, and a 'Kommune' or municipality with responsibilities including education and culture (Färber 2014: 124). Its budgets were 
strongly affected by the transformation of welfare provision under the national programme of 'Agenda 2010' (implemented from 2003 onwards), a 'Third Way' type programme aimed at creating a workfare regime. Most crucially, these reforms included the transfer of costs for social welfare from the national to the local level, placing extreme pressures on the budgets of municipalities in the 2000s (Färber, 2014: 124-5).

However, austerity in Berlin has its roots in the 1990s, as wildly unrealistic predictions about Berlin becoming a 'Global City' gave way to the realities of increasing unemployment, competitive economic disadvantage accrued from Cold War isolation, the challenges of merging the two halves of the city and political mismanagement (Beveridge, 2011; Bernt et al., 2013; Krätke, 2004). In the second half of the 1990s the outlines of an austerity programme emerged under the CDU-SPD coalition government. Partial privatisations of electricity, gas and water utilities were the most prominent of a more systematic programme of deficit reduction, shrinking government and cuts to the social welfare budget, which was rolled out through the first decade of the 2000s. This was exacerbated by the socalled Banking Scandal of 2001, in which the public-private 'Bankgesellschaft Berlin' collapsed on the back of failed speculative real estate investments and left the state of Berlin with a deficit of around 30 Billion euros and brought increased intensity to austerity measures in the years following.

In the domain of housing, austerity-induced changes were significant. First, from 1995 up to 2007 the state of Berlin sold large tranches of its housing stock to the private sector (Uffer, 2013; Holm, 2008), with significant sales even occurring under the coalition of the SPD and the then PDS (and now Die Linke, the Left Party) (Holm et al., 2011). Between 1991 and 2007, when the government stopped the en bloc selling of large housing estate, more than 200000 housing units were privatised, reducing the state-owned housing units by more than 40 percent (Holm, 2008; Fields and Uffer, 2016). In addition to selling off housing stock the state abandoned supply side subsidies. As a result large, capital-rich developers were given an advantage over not-for-profit housing cooperatives, which are often dependent on some sort of subsidy to develop new housing projects.

The sale of public housing units was only possible because the regulation and organisation of the (local) state changed. In the field of housing, a condition for this transformation was the abandonment of the non-profit housing regulation as part of a tax reform on the national level (Uffer, 2013: 136). This not only changed the vision of public housing as such, but also enabled the state of Berlin to extract surplus from their own companies or sell the companies and hence their housing stock to reduce its fiscal debt (Silomon-Pflug and Heeg, 2013). In 2000, the city's executive ('Der Senat von Berlin') established a 
professionalised entity to manage public property and housing units outside the core public administration: the 'Liegenschaftsfond Berlin GmbH \& Co. KG'.

Through the organisational restructuring of state agencies housing policy changed in terms of vision but also administrative practices. Social housing was now understood and also implemented as real estate business similar to private housing agencies. For instance, the public owned housing companies were obliged to sell their real estate at the highest price (Silomon-Pflug, 2013). In the 2007 masterplan for the state owned public housing companies the executive reaffirmed the social goals of public housing. But it incorporated also a profit-making goal in order to pay dividends to the state (see Uffer, 2011: 139-40). As a consequence, rents increased and the management of the public housing stock contributed to the segregation of tenants. As part of a wider austerity induced public sector reform, Liegenschaftsfond turned the public housing stock into an asset to be utilised by the government for different purposes and, second, housing policy was "depoliticised", shifted to a different arena dominated by professionals (Flinders and Buller, 2006) and geared towards profit-making.

Austerity policies in Berlin in the domain of housing are an illustrative case of "scalar dumping" of fiscal discipline (Peck, 2012). Local government public assets were privatised and services were outsourced in order to cope with the fiscal challenges of austerity (Pill \& Guarneros-Meza, 2018). The consequences were a part-retreat of the state from the sector and an adjustment to the goals the remaining state-owned housing companies had to pursue. In other terms, the state reorganised itself towards a networked form of governance based on goals and organisational principles more in line with the private sector. The result was the commodification of the housing market in Berlin and the geographically uneven development of the existing public housing stock with different results for different segments of the tenants. As the German economy in general and the economy in Berlin in particular grew this has translated into steep increases in rents over the last decades.

\section{Struggles against Berlin's housing policy}

The transformation of housing policy in Berlin has not gone unchallenged. The latest and arguably the most pronounced manifestation against the current policy and its effects became apparent in late 2018 . A broad coalition of housing activists formulated a citizen's initiative or petition (Volksbegeheren: Deutsche Wohnen \& CO Enteigen) that can, if it secures the backing of enough residents in Berlin, force the state of Berlin to enact a law that enables the state to remunicipalise the housing stock of large real estate companies. More precisely, the initiative demands that private real estate companies who own more than 3000 housing units should be expropriated and the housing stock should be transferred to common property ("Gemeineigentum"). Compensation should be well below market 
price and the communalised housing stock should then be administered by a not-for profit public-law institution with the participation of residents and tenants of Berlin.

This latest struggle against Berlin's housing policy under austerity encapsulates much of what might be defined as transformative (anti-)politics. First, it seeks to by-pass representative politics through the use of an instrument of direct democracy to change housing policy. Resort to a citizens' petition is indicative of both a scepticism towards established formal institutions of interest articulation and policy making and the reliance on more horizontal and movement-like ways of political action and subjectivation. More fundamentally, while the demand to socialise housing seems at first glance to be a sign of trust in the state, a closer look reveals that it is not. The Volksbegehren makes it clear that the expropriation should be pursued in the name of the urban society and not in the name of the (bureaucratic) state. The Volksbegehren draws literally on this distinction between a state-embedded form of politics and one that enacts an urban based rationality of commoning the city. The resolution's uses the terms "socialisation" (Vergesellschaftung) and "remunicipalisation" (Rekommunalisierung) and does not refer to a direct return to the state (Verstaatlichung). Hence, it is not just another demand directed towards the state as such but it addresses the municipality and the urban society as political authorities distinct from but interwoven with the state. Second, it confronts in a direct manner the efficacy of the private sector to organise, allocate and to supply housing and, more generally, urban land and space. Third, the goal of the initiative is not solely to start a process of decommodification of the existing housing stock, but also to unleash a process of democratising the way vital urban resources are governed. In their resolution for a law for the socialisation of land (Beschluss für ein Vergesellschaftungsgesetz von Grund und Boden) on 25 October 2018, the coalition behind the initiative states that in the governing board of the to-be-formed public institution tenants, employees and "representatives of the urban society ... regardless of their status of citizenship" should hold the majority over representatives of the city's executive.

The coalition pushing the initiative forward is broad and encompasses much of the social groupings that Mayer (2013: 11) has identified as specific for contemporary urban movements: radical autonomous groups, middle-class urbanites, disparate groups that share a precarious existence to marginalized and excluded people (Vollmer, 2019: 120-148). Some are experienced organisations when it comes to such initiatives (Mietenvolksentscheid 2015), some groups are established tenant organisations (Mieterforum Berlin) and also party members and general leftist movements and organisations support the initiative. But there are also newer groups involved such as 'Kotti\&Co', which has taken a leading role and has been prominent in recent housing struggles in the city. 
The participation of Kotti\&Co. is particularly noteworthy because its formation and practices are deeply grounded in the everyday experience of the effects of housing policies shaped by austerity. Those involved in Kotti\&Co. share experiences of exclusion and precariousness. This is the foundation of a collective identity even though their everyday experiences are different (Vollmer, 2019: 187-191). Among members of the Kotti\&Co., there is a general mistrust towards formal institutions of the state and politicians as they blame agents and policies of the state along with market mechanisms for their situation. In their understanding Kotti\&Co. acts outside formal political institutions. But Kotti\&Co.'s struggle cannot be understood simply as a fight against the state. Rather, it might be said that because the organisation has little confidence in formal politics, they demand more self-government. Hence, democratisation should not only take place within formal political institutions but also and perhaps first and foremost through self-governing the urban everyday (Vollmer, 2019: 224-225).

The latest campaign against housing policy under austerity in Berlin is instrumental to understand the broader political situation we see in many European cities. The long history of austerity in Berlin has undermined confidence in the workings of the state. Political practices emerged that are more embedded in the urban everyday than in formal political venues. While the local state recedes from view it is still present in the political struggles. But transformative political projects address and reimagine the local state in a differentiated way. The local state is not pictured as the sole political authority that might resolve societal problems. On the contrary, agents and processes of state politics are seen as the cause of exclusion and precarity in the first place. The state is thus addressed as a decentred entity containing different logics and possibilities. Thereby the local state becomes a strategic plane for an urban society to govern itself. At the intersection of state-led austerity and anti-politics, resistance and demands for self-government revolve around how the local state should operate. The urban everyday as political horizon emerges not in opposition to the state but rather as a force to further de-centre political authority. In the following sections we reflect on these lines of argument further.

\section{The local state as a strategic plane of austerity anti-politics}

We argue above that the state-society binary often invoked in debates on anti-politics might be somewhat deceptive because austerity itself changes and blurs the boundaries between the two with different effects. In the Berlin case but also in other European cities, we can ascertain that the local state has been reshaped and reconfigured under austerity. In Berlin, the Liegenschaftsfond and, earlier on, the abandonment of the not-for-profit housing regulation, introduced new agents, institutional rules and normative ideas to the local housing policy framework. This led to more market-based practices within the local administration in the domain of housing. In turn however housing struggles 
intensified but also changed in terms of how the state is understood and addressed. Formal politics, the target of anti-politics, has already been transformed and more often than not undermined by austerity.

The anti-austerity struggles mentioned in this paper convey the complexity of the local state. They point to plural logics and often incoherent normative frames guiding local policies. In Berlin, the conflicting goals of public housing as both a redistributive policy and a profit generating operation were apparent. Under these conditions it is far from self-evident that "austerity can be governed" or that austerity reinforces by necessity the hegemonic character of neoliberalism, as research in the CURA project has shown (Davies et al., 2018; Blanco et al., 2019). Yet, it is also far from guaranteed that austerity and further economic crisis lead to political situations conducive to emancipatory political goals. Political authority in this context is fluid, heterogenous and not decisive.

Further, a transformed local state entails opportunities for political actions that are not at hand in a context where the state preserves its sovereignty, bureaucratic domination and legitimacy either on the national or local level. Thus it should not comes as a surprise that many anti-austerity struggles perceive formal politics, representative channels of interest articulation and implementation, as wanting and unproductive. Some activists aim to transform parts, nodes or processes within the local state for their own advantage. A slowly disaggregating state does not imply that political authority or the legitimacy of collective forms of governance dissolves at all scales. But it does mean that the (local) state in its institutional form is not the only, possibly not even the most important, addressee of political demands. The Volksbegehren in Berlin, mentioned above, is indicative of this. The resolution itself is directed to the local state and, as a form of petition, attempts to change state policy. But the resolution does not aim to restore the authority of the (local) state but rather aspires to further transform it by fostering processes and practices of direct democracy and self-government for urban citizens. The vision of the local state apparent is one more embedded in urban society and more nurtured by the urban everyday, not the sole arbitrator or source of political authority. This can be read as an attempt to make the local state more hybrid (see Pill and Guarneros-Meza, 2018) in the sense of encouraging the enmeshing of local state organisations and non-state organisations grounded in urban society.

In a context where the division between state and autonomous forms of collective actions is blurred, the local state as a plane of politics becomes problematised. The idea of a new, radical municipalism (Russell, 2019) can be perceived in this manner. There is an attempt to explore the possibilities of collective forms of political actions that go beyond horizontalisms vs. verticality and is concerned with 
the co-production of public policies in the service of urban residents. The local state as an organisational form of collective action remains important but only as fair as institutional logics and practices are adapted to claims for self-government and everyday needs.

What the cases presented here show is that rolling out austerity policies, as Peck (2012) claims, reshapes cities and how the local state operates. As a result it alters the focus and terrain of politics itself shaping the contestations, which emerge in response to it. Anti-austerity struggles in cities reimagine the local state in different ways and turn the local state to a strategic plane for transformative politics. The quest for transformation strives for self-government and a politics that is realigned to the urban everyday; there is, we claim, an undeniable urban horizon to anti-politics in and against austerity in cities.

\section{The urban horizon of (anti-)politics}

The cases detailed above show that political resistances to austerity are not merely defined by their urban settings. They also embody an urbanized from of politics which reacts to and produces more informalized patterns of political authority grounded in the urban (Boudreau, 2017). As such they differ from a "politics of transformation" (Peck, 2012) embedded in formal political institutions and they go beyond an "urbanism of minor practices" (Tonkiss, 2013: 323) that focuses mainly on the transformation and creation of material spaces. We are not claiming that they are all necessarily novel. Rather our point is that resistance to austerity often resembles an "urban logic of action" (Boudreau, 2017) observable across a variety of contexts.

Over recent decades scholars have attempted to find the common threads linking diverse events, activisms, movements and non-movements which are not simply - if at all in many cases - against formal politics but seem to exist on completely different terms or operate in different registers and follow alternative logics (e.g. Rodgers et al., 2014; Mitchell et al., 2015; McFarlane, 2016. Increasingly, urban researchers no longer take sovereignty and the nation state to be at the centre of politics. This might be the urban politics of social movements (Boudreau et al., 2009), nonmovements (Bayat, 2010), planning (Nicholls and Uitermark, 2017), the politicization of immigrants (Nicholls, 2016) or the urban fabrication of neighbourhoods (Hentschel, 2015). There is a sense that politics has become more urban, that the urban has become more political and this rests on the (renewed) sense of the political potential of the urban itself (Beveridge and Koch, 2019). 
What is distinctive about this urban rationality? In the examples above, we find a strong focus on urban everyday life as a site of political activism. It is in and against the background of the everyday that organisations, such as Kotti\&Co., form new political alliances. People meet in the everyday and discuss issues concerned with the everyday. Hallways or front yards of housing estate turn into locations for political organization and contestation. People come together because they share elements of the urban everyday. The common ground for political agency is not a pre-existing political affiliation or shared identity but the mutual awareness of inequality or discrimination embedded in the urban everyday.

Further, the anti-austerity struggles mentioned in this article perceive of the urban not just as site or stage but crucially as their stake. The urban is understood in this regard not only as a distinct institutional level of political organization but rather as a resource of societal self-organization and democratic politics. Self-government as a means and end of being political shapes relations, practices and organizational "structures", where sovereignty is contested and deferred rather than installed and reproduced (cf. Magnusson, 2011). Hence state politics is not eclipsed by but is met by urban politics.

The anti-politics we have identified here as arising in and against austerity in cities should not be reduced to a politics of a particular political level or a politics sans the state. Rather it is a different, more urban, form of politics. The urban and the state rationalities of politics meet, as we have seen in the examples detailed above, in local state spaces. The local state becomes a crucial political field of contestation against austerity programs but, at the same time, turns into the site where urban society experiments with forms of self-government and activism embedded in the everyday experiences of citizens.

\section{Conclusion}

Our overall aim in this article has been to re-think anti-politics and, indeed, politics, from an urban perspective, drawing on austerity struggles in European cities. We have argued, that in a context of austerity state-centred understandings of politics are lacking: the state is no longer recognized as "the main interlocutor in the political process" (Boudreau, 2017: 60). And in moving to a more urban form of politics, we need to appreciate that power is dispersed, political practices and logics are entangled with spatial claims and processes of urbanization and are not only aimed at formal political power (Magnusson, 2011) Ultimately, however, our arguments retain an exploratory quality. In this 
concluding section, we attempt to highlight the potential of an urban logic of political action in the current political conjuncture.

The struggles against austerity outside and often in opposition to formal political institutions demonstrate that there are alternatives to austerity (Davies, 2017). More importantly, these alternatives are not limited to policy choices but encompass how citizens organize self-governing activities. We should remain realistic about the potential of political struggles against austerity given the severity of the situation in many places and the limited success of many movements within this context. Our purpose here has been to show that some anti-austerity struggles are opening up new possibilities to think and act politically. Alongside the populist right-wing reaction that calls for more national sovereignty and the "centrist" liberal proposition for more markets and competition there are alternatives grounded in an urban logic of political action, embedded in the urban everyday and motivated by the vision of self-government.

Anti-austerity struggles as described here are transformative in their thrust. They articulate a collective stake in the city mainly but not exclusively by demanding or enacting the commoning of urban resources (such as housing). The coproduction and shared property of urban spaces challenges institutionalized norms and ideas of the relation between the material and social form of the city based on individual private property. The claim for an urban commons trope we observe in numerous cities (see section 3) articulates an antagonism, de-centres the state and thus expands the boundaries of the political realm beyond the immediate struggle against austerity. What is more, the claim facilitates both explicitly and implicitly -the building of political alliances. These alliances are often not predefined by existing political affiliations or identities but are, instead, grounded in the urban everyday. Based on our analysis we concur with Mayer's $(2013,13)$ contention that struggles against austerity may have the potential to forge connections between existing urban movements and emerging political subjects. The urban everyday as a site of political subjectivation but also as a shared experience and focus of political change is crucial to understand this emerging politics of solidarity (cf. Beveridge and Koch, 2019).

In the struggles against austerity observed the local state is not wished away. Often the urban alliances discussed here invoke the possibilities and limitations of the local state when articulating the antagonism between an urban commons and private property. However, this is not the local state as it is but rather a reimagined one. The local state still seems to offer opportunities, even if the wider institutions of liberal democracy and the nation state do not. The moves of city government and social 
movements, such as 'Solidarity Cities', to establish alternative to the punitive immigration policies of nation states seem to be in line with this political strategy.

The political practices discussed in our paper are, however, not without ambiguities as some scholars have correctly argued (Stehlin \& Tarr, 2017). A politics of everyday resilience can be completely congruent to a neoliberal/austerity political agenda unless it articulates or enacts antagonisms and confronts this agenda (Rosol, 2012). The reproduction of uneven development may occur, for instance, in middle class responses to a crisis mainly experienced by lower income groups (McClintock, 2018). A politics of self-enclosed communities can take hold, one that is unresponsive to other struggles and other communities in other places and at different scales (McClintock, 2018). Furthermore, responses to austerity themselves can be appropriated as new forms of cultural place-making policy totally in line with neoliberal policies or even fostered by the urban elite: "branding and place marketing is central to urban growth strategies for coping with and moving beyond austerity. Some cities selectively integrate cultural and ethnic diversity into their branding" (Davies, 2017: 3).

Despite these reservations, we maintain that urban struggles against austerity do a radical anti-politics. The article has argued that new possibilities for achieving transformative political change can emerge through the rejection of the terms and limits of the dominant ways of doing politics - centred on formal political institutions and the state as the final arbiter of political possibility. While we may not free ourselves entirely from the state, or even want to, alternative framings of political struggle and change are apparent, both empirically and conceptually.

Hostility to formal politics was on the rise even before the financial crisis in many countries, but austerity politics has certainly acted as a catalyst: casting the state not only as responsible for the crisis but also as the implementer of regressive redistributive policies (Peck, 2012). In this way, austerity can be seen to further destabilize the political system. As an "inevitable truth" austerity contributes to a further depoliticization of the formal political realm. As we argue in this paper, however, austerity is also generative of new political opportunities. To grasp their significance for a wider project of democratization, we need to critically reflect on how the state-society binary shapes our understanding of what counts as politics and anti-politics. We claim that faced with austerity policies political resistance shifts the plane of politics as such. (Anti-)politics in and against austerity is specific because its vision is not (only) to make better, fairer policies but to transform the way we think and act politically. 


\section{Bibliography}

Abensour M (2011) Democracy Against the State: Marx and the Machiavellian Movement. Cambridge: Polity.

Arampatzi A (2017) Contentious spatialities in an era of austerity: Everyday politics and 'struggle communities' in Athens, Greece. Political Geography 60: 47-56.

Barnett C (2017) The Priority of Injustice. Locating Democracy in Critical Theory. Athens: The University of Georgia Press.

Bayat A (2010) Life as Politics: How Ordinary People Change the Middle East. Stanford: Stanford University Press.

Bernt M, Grell B and Holm A (2013) (eds) The Berlin Reader: A Compendium on Urban Change and Activism. Bielefeld: transcript.

Beveridge R (2011) A Politics of Inevitability. Wiesbaden: VS Verlag für Sozialwissenschaften.

Beveridge R and Koch P (2017a) The post-political trap? Reflections on politics, agency and the city. Urban Studies 54(1): 31-43.

Beveridge R and Koch P (2017b) What is (still) political about the city?. Urban Studies 54(1): 62-66.

Beveridge R and Koch P (2019) Urban everyday politics: Politicising practices and the transformation of the here and now. Environment and Planning D: Society and Space 37(1): 142-157.

Beveridge R, Hüesker F and Naumann M (2014) From post-politics to a politics of possibility? Unravelling the privatization of the Berlin Water Company. Geoforum 51: 66-74.

Blanco I (2015) Between democratic network governance and neoliberalism: A regime-theoretical analysis of collaboration in Barcelona. Cities 44: 123-130.

Blanco I, Salazar Y and Bianchi I (2019) Urban governance and political change under a radical left government. The case of Barcelona. Journal of Urban Affairs. Epub ahead of print 24 January 2019. DOI: $10.1080 / 07352166.2018 .1559648$

Blomley N (2019) The territorialization of property in land: space, power, and practice. Territory, Politics, Governance 7(2): 233-249.

Blomley N (2017) Land use, planning, and the 'difficult character of property. Planning Theory and Practice 18: 351-364.

Boudreau JA (2017) Global Urban Politics: Informalization of the State. Cambridge: Polity.

Boudreau J-A, Boucher N and Liguori M (2009) Taking the bus daily and demonstrating on Sunday: Reflections on the formation of political subjectivity in an urban world. City 13(2/3): 336-346.

Bresnihan P and Byrne M (2015) Escape into the City: Everyday Practices of Commoning and the Production of Urban Space in Dublin. Antipode 47: 36-54.

Brooks D (2016) The Governing Cancer of Our Time. The New York Times, 26 February. Available at: https:/www.nytimes.com/2016/02/26/opinion/the-governing-cancer-of-our-time.html (accessed 4 June 2019).

Clarke N (2015) Geographies of politics and anti-politics. Geoforum 62: 190-192.

Clarke N, Jennings W, Moss J and Stoker G (2018) The Good Politician: Folk Theories, Political Interaction, and the Rise of Anti-Politics. Cambridge: Cambridge University Press.

Clarke N, Jennings W, Moss J and Stoker G (2016) Anti-politics and the Left. Renewal 24(2): 9-18.

Crouch C (2004) Post-democracy. Cambridge: Polity. 
Daskalaki M (2017) Alternative organizing in times of crisis: Resistance assemblages and socio-spatial solidarity. European Urban and Regional Studies 25: 155-170.

Davidson M and Ward K (2018) Introduction. In: Davidson M and Ward K (eds) Cities under Austerity: Restructuring the US Metropolis. Albany: SUNY Press, pp. 1-26.

Davies JS (2017) Governing in and against austerity: International lessons from eight cities. Report, De Montfort University, Leicester, UK.

Davies JS and Blanco I (2017) Austerity urbanism: Patterns of neo-liberalisation and resistance in six cities of Spain and the UK. Environment and Planning A: Economy and Space 49(7): 15171536.

Davies JS, Bua A, Oriol MC and Thomson E (2018) Why is austerity governable? A Gramscian urban regime analysis of Leicester, UK. Journal of Urban Affairs. Epub ahead of print 15 August 2018. DOI: 10.1080/07352166.2018.1490152.

Della Porta D (2013) Can Democracy Be Saved? Participation, Deliberation, and Social Movements. Cambridge: Polity.

Di Feliciantonio C (2017) Spaces of the Expelled as Spaces of the Urban Commons? Analysing the Reemergence of Squatting Initiatives in Rome. International Journal of Urban and Regional Research 41: 708-725.

Färber A (2014) Low-budget Berlin: towards an understanding of low-budget urbanity as assemblage. Cambridge Journal of Regions, Economy and Society 7: 119-136.

Fawcett P, Flinders M, Hay C and Wood C (2017) Anti-Politics, Depoliticization, and Governance. Oxford: Oxford University Press.

Fields D and Uffer S (2016) The financialisation of rental housing: A comparative analysis of New York and Berlin. Urban Studies 53(7): 1486-1502.

Flinders M (2012) Defending Politics: Why Democracy Matters in the 21st Century. Oxford: Oxford University Press.

Flinders M and Buller J (2006) Depoliticisation: Principles, Tactics and Tools. British Politics 1(3): 293318.

Fuller C and West K (2017) The possibilities and limits of political contestation in times of 'urban austerity'. Urban Studies 54: 2087-2106.

Gaynor N (2018) Governing austerity in Dublin: Rationalization, resilience, and resistance. Journal of Urban Affairs. Epub ahead of print 3 August 2018. DOI: 10.1080/07352166.2018.1484256.

Hardt M and Negri A (2000) Empire. Cambridge: Harvard University Press.

Hay C (2007) Why we hate politics. Cambridge: Polity.

Hearne R (2015) The Irish water war. Interface 7(1): 309-321.

Hentschel C (2015) Postcolonializing Berlin and The Fabrication of the Urban. . International Journal of Urban and Regional Research 39(1): 79-91.

Holm A (2008) Neuordnungen des Städtischen in kapitalistischen Gesellschaften. Marxistische Blätter 46: $13-21$.

Holm A (2014) (ed) Reclaim Berlin! Soziale Kämpfe in der neoliberalen Stadt. Berlin/Hamburg: Assoziation A.

Holm A, Lederer K and Naumann M (2011) (eds) Linke Metropolenpolitik. Erfahrungen und Perspektiven am Beispiel Berlin. Münster: Westfälisches Dampfboot. 
Hodkinson S (2012) The new urban enclosures. City 16: 500-518.

Jessop B (2016) The heartlands of neoliberalism and the rise of the austerity state. In: Springer S, Birch K and MacLeavy J (eds) The handbook of neoliberalism. London: Routledge, pp. 410 - 421.

Krätke S (2004) City of talents? Berlin's regional economy, socio-spatial fabric and 'worst practice' urban governance. International Journal of Urban and Regional Research 28: 511-529.

Kriesi HP (2014) The populist challenge. West European Politics 37: 361-378.

Leonard M (2014) Rage against the machine: the rise of anti-politics across Europe. New Statesmen, 5 June. Available at: www.newstatesman.com/politics/2014/06/rage-against-machine-rise-antipolitics-across-europe (accessed 4 June 2019).

McClintock N (2018) Cultivating (a) Sustainability Capital: Urban Agriculture, Ecogentrification, and the Uneven Valorization of Social Reproduction. Annals of the American Association of Geographers 108: 579-590.

McFarlane C (2016) The geographies of urban density: Topology, politics and the city. Progress in Human Geography 40(5): 629-648.

Magnusson W (2014) The symbiosis of the urban and the political. International Journal of Urban and Region Research 38: 1561-1575.

Magnusson W (2011) Politics of urbanism: seeing like a city. London: Routledge.

Mair P (2013) Ruling the void: The Hollowing of Western Democracy. London: Verso.

Marchart O (2015) Demokratischer Radikalismus und radikale Demokratie. Historischprogrammatische Anmerkungen zum Stand politischer Theorie. Berliner Debatte Initial 26(4): $21-32$.

Mayer M (2013) First world urban activism: Beyond austerity urbanism and creative city politics. City 17: 5-19.

Mitchell D, Attoh K and Staeheli L (2015) Whose city? What politics? Contentious and noncontentious spaces on Colorado's Front Range. Urban Studies 52(14): 2633-2648.

Newman S (2011) Postanarchism: a politics of anti-politics. Journal of Political Ideologies 16: 313-327.

Newman S (2015) Postanarchism. Cambridge: Polity.

Nicholls WJ (2016) Politicizing undocumented immigrants one corner at a time: How day laborers became a politically contentious group. International Journal of Urban and Regional Research 40(2): 299-320.

Nicholls W and Uitermark J (2017) Introduction: Planning/resistance. Urban Geography 38(4): 512520.

O'Callaghan C, Di Feliciantonio C and Byrne M (2018) Governing urban vacancy in post-crash Dublin: contested property and alternative social projects. Urban Geography39(6): 868-891.

Peck J (2012) Austerity Urbanism: American cities under extreme economy. City 16: 626-655.

Pill M (2018) The austerity governance of Baltimore's neighborhoods: 'The conversation may have changed but the systems aren't changing. Journal of Urban Affairs. Epub ahead of print 14 June 2018. DOI: 10.1080/07352166.2018.1478226.

Pill M and Guarneros-Meza V (2018) Local governance under austerity: hybrid organisations and hybrid officers. Policy \& Politics 46(3): 409-425.

Rancière J (2009) Hatred of Democracy. London: Verso. 
Rodgers S, Barnett C and Cochrane A (2014) Where is urban politics?. International Journal of Urban and Regional Research 38(5): 1551-1560.

Rosol M (2012) Community Volunteering as Neoliberal Strategy? Green Space Production in Berlin. Antipode 44: 239-257.

Russell B (2019) Beyond the Local Trap: New Municipalism and the Rise of the Fearless Cities. Antipode 51(3): 989-1010.

Schedler A (1997) (ed.) The End of Politics? Explorations into Modern Antipolitics. London: Palgrave MacMillan.

Silomon-Pflug F and Heeg S (2013) Neoliberale Neuordnung städtischer Verwaltungen am Beispiel des Liegenschaftsfonds Berlin. Geographische Zeitschrift 101: 184-200.

Stavrides S (2014) Emerging common spaces as a challenge to the city of crisis. City 18: 546- 550.

Stehlin JG and Tarr AG (2017) Think regionally, act locally? Gardening, cycling, and the horizon of urban spatial politics. Urban Geography 38: 1329-1351.

Streeck W and Mertens D (2011) Fiscal austerity and public investment: is the possible the enemy of the necessary?. MPIfG Discussion Paper 11/12, Cologne, Germany.

Streeck W (2016) How will capitalism end? Essays on a failing system. London: Verso.

Stoker G (2006) Why politics matters: making democracy work. London: Palgrave Macmillan.

Tonkiss F (2013) Austerity urbanism and the makeshift city. City 17: 312-324.

Tormey S and Gagnon JP (2017) The End of Representative Politics, Revisited. Democratic Theory 4(2): 82-101.

Tormey S (2015) The end of representative politics. Cambridge: Polity.

Uffer S (2011) The Uneven Development of Berlin's Housing Provision. PhD Thesis, LSE, UK.

Uffer S (2013) The Uneven Development of Berlin's Housing Provision. In: Bernt M et al. (eds) The Berlin Reader. Bielefeld: transcript, pp. 155-170.

Vollmer L (2019) Mieter_innenbewegungen in Berlin und New York: Die Formierung politischer Kollektivität. Wiesbaden: Springer VS.

Wainwright H (2018) A New Politics from the Left. Cambridge: Polity.

Wilson J and Swyngedouw E (2014) (eds) The Post-Political and Its Discontents: Spaces of Depoliticisation, Spectres of Radical Politics. Edinburgh: Edinburgh University Press. 